\title{
Dosage and Duration Effects of Korean Red Ginseng Intake on Frequency of Gross Deletions in the nef Gene
}

\author{
Young Keol Cho* and You Sun Jung \\ Department of Microbiology, Asan Medical Center, University of Ulsan College of Medicine, Seoul 138-040, Korea
}

In the present study, we investigated whether a gross deletion in the nef gene ( $\mathrm{g} \Delta$ nef) is induced by Korean red ginseng (KRG) intake. Ten patients were treated with KRG powder for 3 years in the absence of antiretroviral drug therapy. On average, $3,555 \pm 1,042 \mathrm{~g}$ KRG was administered per person over $36.1 \pm 2.4$ months. There was a mild decrease in CD4 T cell count $(75 \pm 110 / \mu \mathrm{L})$ over the $36.1 \pm 2.4$ months $(p=0.059)$. We obtained 355 nef amplicons using 71 peripheral blood mononuclear cell samples over a 3-year period. All ten patients exhibited g $\Delta$ nef (range, 3.2 to $45.9 \%$ ). At baseline, 3 of 78 amplicons (3.8\%) exhibited $\mathrm{g} \Delta n e f$, whereas $18.8 \%$ (52/277) revealed $\mathrm{g} \Delta n e f$ during KRG-intake $(p<0.001)$. The proportion of $\mathrm{g} \Delta n e f$ was significantly correlated with monthly dose of $\mathrm{KRG}(r=0.89, p<0.001)$. The median time for first detection of $\mathrm{g} \Delta n e f$ was 13 months. In conclusion, our data show that $\mathrm{g} \Delta$ nef is inducible by KRG intake and its proportion is dependent on the duration of KRG intake and dose of KRG.

Keywords: AIDS, HIV-1, nef, Korean red ginseng, Gross deletion

\section{INTRODUCTION}

Gross deletions or genetic defects in the human immunodeficiency virus (HIV)-1 gene in HIV-1 infected patients are very rare [1-3]. Thus, it is known that genetic defects may not be a common characteristics among long-term nonprogressors (LTNPs)/long-term survivors (LTS) or elite controllers. However, gross deletions in the $n e f$ gene $(\mathrm{g} \Delta n e f)$ have been reported in many LTNPs $[4,5]$. However, limitations in most of these studies, such as small patient numbers or absence of appropriate control groups, have hindered interpretation of results [6]. Highly active antiretroviral therapy (HAART) has reduced mortality and morbidity related to human immunodeficiency virus diseases [7]. However, treatment with all antiretroviral agents selects for drug-resistant mutations in the HIV-1 gene that ultimately result in therapy failure. To my knowledge, there is no report that describes any treatments that attenuate HIV-1 (or other) viruses.

Panax ginseng C. A. Meyer has been used as a drug for more than 2,000 years [8]. Recently, many reports put a high value on ginseng as immune modulator and adjuvant $[9,10]$. In 1991, we began treating HIV-1 infected patients with Korean red ginseng (KRG) for 6 months and observed that KRG-intake had various beneficial effects, including increases in CD4 and CD8 T cell counts [11-13]. We subsequently reported that KRG slows depletion of CD4 T cells in HIV-1-infected patients over 10 years [14-17]. We also showed that there was a high frequency of g $\Delta$ nef in LTS [18] and hemophiliacs [19] that had been treated with KRG; in this latter group, there was a dose-dependent relationship between KRG intake and the frequency of $\mathrm{g} \Delta n e f$. In ad-

\footnotetext{
(c) This is an Open Access article distributed under the terms of the Creative Commons Attribution Non-Commercial License (http://creativecommons.org/licenses/by-nc/3.0/) which permits unrestricted non-commercial use, distribution, and reproduction in any medium, provided the original work is properly cited.
}

Received 26 May 2010, Revised 18 Jul. 2010, Accepted 23 Jul. 2010

*Corresponding author

E-mail: ykcho2@amc.seoul.kr

Tel: +82-2-3010-4283, Fax: +82-2-3010-4259 
dition, the frequency of a gross deletion in the 5'-LTR/ gag in these KRG-treated patients was 2-fold higher

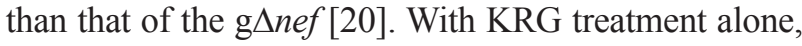
several patients among less than $100 \mathrm{HIV}-1$ infected patients diagnosed prior to 1991 remained healthy for 20 years after diagnosis [20,21], and we recently showed that combined treatment with HAART plus KRG was more beneficial than HAART only [22].

However, despite demonstrating a strong association between the occurrence of g $\Delta$ nef and KRG intake, our previous study was unable to define the time at which the first gross deletion occurred during KRG intake due to the absence of baseline data and samples collected prior to 3 years after initiating KRG intake $[18,19]$. In the present study, we investigated the time to first occurrence of a g $\Delta$ nef in ten patients for whom baseline and/or earlier samples were available. Our data show that $\mathrm{g} \Delta$ nef is inducible in all patients within 30 months of KRG intake and its proportion depends on the duration and dosage of KRG intake.

\section{MATERIALS AND METHODS}

\section{Study population}

Among our cohort, ten patients infected with subtype B of HIV-1 and treated with KRG were selected. Inclusion criteria were consistent intake of KRG for up to 3 years and availability of at least five samples for 3 years in the absence of HAART. We excluded hemophiliacs because these patients were infected with HIV-1 through a different mode of transmission [23]. Patients infected with non-subtype B were also excluded. All patients were diagnosed between 1989 and 2004 (Table
1). Except 2 patients (95-87 and 96-51), they had not taken KRG prior to this study. Eight patients were male and two were female. Informed written consent was obtained from all subjects before the initiation of the study.

\section{Therapy with Korean red ginseng}

KRG treatment in HIV-1-infected patients was begun on an outpatient basis at the Korean National Institute of Health in late 1991 [11,12]. The daily dose of KRG was $5.4 \mathrm{~g}$ for men and $2.7 \mathrm{~g}$ for women [22]. On average, 3,555 $\pm 1,042 \mathrm{~g} \mathrm{KRG}$ was administered over the course of $36.1 \pm 2.4$ months.

\section{CD4 T cell counts and plasma HIV-1 RNA copy num- bers}

Blood was drawn from each patient at 3- to 6-month intervals, and peripheral blood mononuclear cells (PBMCs) in each sample were incubated with phycoerythrin- and fluorescein isothiocyanate-conjugated antibodies (combined in the Simultest reagent; Becton Dickinson, San Jose, CA, USA) against CD4 and CD8 antigens, respectively. Levels of CD4 and CD8 T cells were measured by flow cytometry using FACScan (Becton Dickinson). Plasma concentrations of HIV-1 RNA were measured using the Amplicor HIV-1 Monitor kit (Roche Diagnostics, Branchburg, NJ, USA) [16].

\section{Amplification of the nef gene}

Proviral DNA was extracted from uncultured PBMCs. nef amplicons were amplified from each sample by double-nested (rarely, triple-nested) PCR as described elsewhere [18,19].

Table 1. Baseline characteristics of $10 \mathrm{HIV}-1$-infected patients and outcome

\begin{tabular}{|c|c|c|c|c|c|c|c|}
\hline Patient code ${ }^{1)}$ & $\begin{array}{c}\text { Sex/age } \\
\text { at diagnosis (yr) }\end{array}$ & $\begin{array}{l}\text { Subtype of } \\
\text { HIV-1 }\end{array}$ & HLA class I & $\begin{array}{l}\text { CD4 T cell } \\
(/ \mathrm{uL})\end{array}$ & $\begin{array}{c}\text { Plasma } \\
\text { RNA copy }\end{array}$ & $\begin{array}{c}\text { Stat time } \\
\text { of this study }\end{array}$ & $\begin{array}{l}\text { Outcome } \\
\text { at present }\end{array}$ \\
\hline $89-14$ & $\mathrm{M} / 29$ & KSB & $\mathrm{A} 2,24 \mathrm{~B} 7,48 \mathrm{C} 7,8$ & 222 & ND & Jan 1992 & Death \\
\hline $91-22$ & $\mathrm{M} / 8$ & KSB & $\mathrm{A} 1,24 \mathrm{~B} 39,52 \mathrm{C} 7,12$ & 316 & 9,400 & Sep 2002 & On KRG \\
\hline $92-48$ & $\mathrm{M} / 47$ & KSB & $\mathrm{A} 24,31 \mathrm{~B} 7,54 \mathrm{C} 1,7$ & 287 & ND & Oct 1992 & Suicide \\
\hline $95-87$ & $\mathrm{M} / 32$ & KSB & $\mathrm{A} 2,24 \mathrm{~B} 48,67 \mathrm{C} 7,8$ & 512 & 44,000 & Jun 2005 & On KRG \\
\hline $96-51$ & $\mathrm{M} / 28$ & KSB & A2,- B51,61 Cw10,14 & 514 & 29,200 & Jun 2000 & On HAART/KRG \\
\hline $97-116$ & $\mathrm{~F} / 23$ & KSB & $\mathrm{A} 2,-\mathrm{B} 59,67 \mathrm{C} 1,7$ & 330 & 22,100 & Jul 2001 & On KRG \\
\hline $01-99$ & $\mathrm{~F} / 22$ & B & $\mathrm{A} 2,-\mathrm{B} 46,51 \mathrm{C} 1,10$ & 228 & 16,400 & Apr 2001 & On KRG \\
\hline $01-179$ & $\mathrm{M} / 50$ & KSB & A 31,33 B44,61 Cw10 & 407 & 134,508 & Jul 2004 & On KRG \\
\hline $03-493$ & $\mathrm{M} / 45$ & KSB & $\mathrm{A} 2,-\mathrm{B} 27,46 \mathrm{C} 1,5$ & 716 & 7,671 & Jan 2005 & On KRG \\
\hline $04-397$ & M38 & KSB & $\mathrm{A} 24,-\mathrm{B} 35,-\mathrm{Cw} 9,-$ & 450 & 530,000 & Nov 2004 & On HAART \\
\hline
\end{tabular}

Two digits prior to hyphen means year of HIV-1 diagnosis.

HIV, human immunodefi ciency virus; KSB, Korean subclade B of HIV-1; ND, not determined, however, p24 was positive in serum; KRG, Korean red ginseng; HAART, highly active antiretroviral therapy.

${ }^{1)}$ Patient code means number in national registry. 


\section{HLA typing}

DNA was isolated from PBMC and HLA-A, -B, and -C typing was performed using the amplification-refractory mutation system-PCR method. Each tube contained a primer mix consisting of the allele- or groupspecific primer pairs, as well as a plus control primer matching the nonallelic sequences. There were 32 sets specific for HLA-A, 27 sets for HLA-B, and 23 sets for HLA-C. Details are described elsewhere [16].

\section{Statistical analysis}

Data are expressed as means \pm standard deviations. Statistical significance was estimated by Student's twotailed $t$-test, the chi-square test, Fisher's exact test, or correlation analysis, using SPSS ver. 12.0 (SPSS Inc., Chicago, IL, USA). Statistical significance was defined as $p<0.05$.

\section{Nucleotide sequences}

GenBank accession numbers are HM369809-920, HM369933-040, AY121476, AY221717, DQ121935-948, AY121479, AY221649, AY363353-354, HM369962-970, HM747120, HM747122-123, HM747126-128, HM747130, HM747133, and HM747135-136.

\section{RESULTS}

\section{Viral load and CD4 T cells}

In the eight patients in whom plasma viral RNA copy number was determined (P24 antigen was measured in the remaining two patients) [24], there was a significant correlation between plasma viral RNA level and the decrease in CD4 T cells $(r=0.87, p<0.01)$. In four of eight patients, viral RNA copy number was measured at both baseline and endpoints. In three patients, the changes (1,470 to 9,400 copies/mL, 44,000 to 30,730 copies/ $\mathrm{mL}$, and 22,100 to 34,839 copies $/ \mathrm{mL}$ ) were not significant. However, in one patient with a high baseline level of viral RNA (530,000 copies $/ \mathrm{mL})$, viral copy number increased to $4,755,746$ copies $/ \mathrm{mL}$ over the course of 33 months in association with a continuous decrease in CD4 T cell count from $450 / \mu \mathrm{L}$ to $190 / \mu \mathrm{L}$. This steep decrease in CD4 T cell might be associated with homozygotes at 3 alleles of HLA class I (A24,-B35,- Cw9, -) and the worst prognosis allele B35 $[25,26]$ (Table 2).

\section{Relationship between Korean red ginseng intake and change in CD4 $\mathrm{T}$ cells}

On average, patients consumed 3,555 $\pm 1,042$ g KRG (range, 1,512 to $5,520 \mathrm{~g}$ ) over a time span of $36.1 \pm 2.4$ months. The average monthly dose was $101 \pm 25 \mathrm{~g}$ (range, 63 to $154 \mathrm{~g}$ ). Although there was a trend toward a decrease in CD4 T cell count (from $398 \pm 154 / \mu \mathrm{L}$ to $323 \pm 146 / \mu \mathrm{L}$ ) over the duration of the trial, this corresponds to annual decrease of $24 / \mu \mathrm{L}(p=0.059)$.

\section{Higher frequency of nef gene after KRG intake compared to baseline}

Including 10 samples at baseline or prior to $\mathrm{KRG}$ intake, we collected 71 PBMC samples over 36.1 $1 \pm 2.4$ months from patients on KRG intake for PCR analysis of the ganef. Four reactions for each sample were at-

Table 2. Proportion and onset time of gross deletion in the gAnef during KRG-intake

\begin{tabular}{|c|c|c|c|c|c|c|c|}
\hline Patient & $\begin{array}{l}\text { Monthly KRG } \\
\text { (g) }\end{array}$ & $\begin{array}{c}\text { No. of } \\
\text { PBMC sample }\end{array}$ & $\begin{array}{l}\text { No. of PBMC } \\
\text { with } g \Delta n e f\end{array}$ & $\begin{array}{l}\text { No. of PCR } \\
\text { amplicons }\end{array}$ & $\begin{array}{l}\text { No. of } \\
\mathrm{g} \Delta n e f^{1)}\end{array}$ & $\begin{array}{l}\text { Proportion of } \\
\mathrm{g} \Delta n e f(\%)\end{array}$ & $\begin{array}{c}\text { Time on the first } \\
\text { detection of } \mathrm{g} \Delta n e f \\
\text { from } \mathrm{KRG} \text { intake (mo) }\end{array}$ \\
\hline $89-14^{2)}$ & 109 & 8 & 5 & 35 & 12 & 34.3 & 0 \\
\hline $91-22$ & 79 & 5 & 1 & 18 & 2 & 11.1 & 4 \\
\hline $92-48^{2)}$ & 154 & 8 & 6 & 37 & 17 & 45.9 & 0 \\
\hline $95-87$ & 90 & 6 & 2 & 29 & 2 & 6.9 & 12 \\
\hline $96-51$ & 120 & 4 & 3 & 18 & 5 & 27.8 & 18 \\
\hline $97-116$ & 63 & 7 & 1 & 31 & 1 & 3.2 & 17 \\
\hline $01-99^{2)}$ & 107 & 5 & 3 & 23 & 4 & 17.4 & 0 \\
\hline 01-179 & 88 & 6 & 3 & 30 & 3 & 10.0 & 14 \\
\hline 03-493 & 108 & 7 & 2 & 35 & 4 & 11.4 & 29 \\
\hline 04-397 & 90 & 5 & 2 & 21 & 2 & 9.5 & 14 \\
\hline Total & $101 \pm 25$ & 61 & 28 & 277 & 52 & $17.8 \pm 14$ & 13 \\
\hline
\end{tabular}

gAnef, nef gene; KRG, Korean red ginseng; HIV, human immunodeficiency virus; PMBC, peripheral blood mononuclear cell.

${ }^{1)}$ Gross deletion in the ganef .

${ }^{2)}$ Three patients revealed one g $\Delta$ nef at baseline, respectively. 


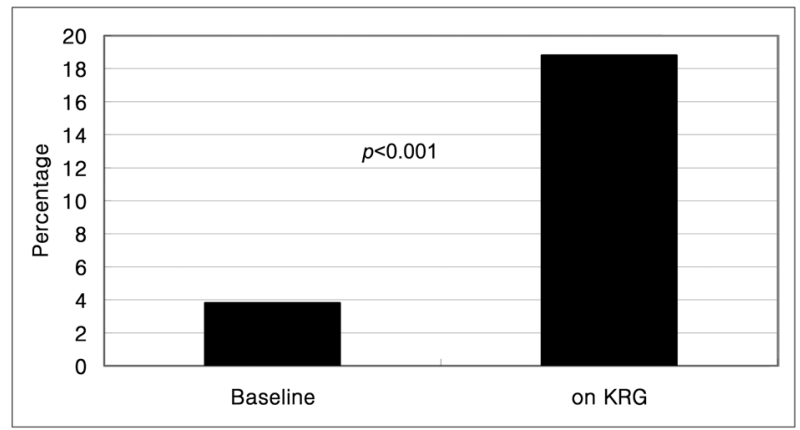

Fig. 1. Comparison of the proportion of $P C R$ amplicons with gross deletions in the nef gene $(g \Delta n e f)$. At baseline, the proportion of $g \Delta$ nef was $3.8 \%(3 / 78)$, whereas during Korean red ginseng (KRG) intake it increased significantly to $18.8 \%(52 / 277)(p<0.001)$.

tempted. Of the 78 amplicons obtained at baseline, 3 amplicons $(3.8 \%)$ from three patients were $\mathrm{g} \Delta$ nef together with wild type. In detail, the three patients (89-

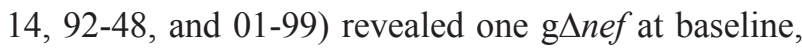
respectively. The proportions were $12.5 \%(1 / 8), 9.1 \%$ $(1 / 11)$, and 7.7\% (1/13), respectively. During KRG intake, we obtained 277 amplicons from 61 PBMC samples. Of these, 52 amplicons (18.8\%) from 28 PBMC samples $(45.9 \%)$ were g $\Delta$ nef $(p<0.01)$ (Fig. 1$)$.

\section{Median time for the detection of first nef gene}

All ten patients exhibited g $\Delta$ nef during KRG intake, with a median time for first detection of $\mathrm{g} \Delta$ nef of 13 months (range, 0 to 29 months) (Table 2). The locations and sizes of gross deletion are described in Table 3 .

\section{Correlation between nef gene proportion, and dose and duration of KRG intake}

The proportion of gross deletions as a percent of amplicons was variable among patients (3.2\% to $45.9 \%)$. The patient (92-48) who revealed the highest proportion took the highest dosage of KRG. He was followed up to 53 months after the end of this study. Overall 50 amplicons were obtained during KRG intake and 25 were grossly deleted (50\%), whereas there was one $\mathrm{g} \Delta$ nef among 11 amplicons before KRG intake (1/11) $(p<0.05)$. There was a significant relationship between the monthly amount of KRG intake and the proportion of $\mathrm{g} \Delta n e f(r=0.89, p<0.001)$ (Fig. 2). To determine whether the proportion of $\mathrm{g} \Delta n e f$ was related to the duration of KRG intake, we divided all 355 PCR amplicons into three 12-month groups (baseline, 1 to 12 months, 13 to 24 months, and 25 to 36 months) according to the duration of KRG intake.

Importantly, we found that the proportion of $\mathrm{g} \Delta n e f$ increased with increasing duration of KRG intake $(p<0.01) ; \mathrm{g} \Delta$ nef proportion was $3.8 \%(3 / 78)$ at baseline, $9.6 \%(7 / 73)$ at 1 to 12 months, $20.4 \%(19 / 93)$ at 13 to 24 months, and $23.4 \%$ (26/111) at 25 to 36 months (Fig. 3).

\section{No premature stop codon in the nef gene}

We determined sequences of 140 wild type nef out of 295 amplicons obtained during KRG intake. There was no premature stop codon or G-to-A hypermutations. However, in patient 01-99, all sequences revealed deletion of 9 base pairs of 9th-11th amino acids from the initiation codon.

\section{DISCUSSION}

Previous report showed that KRG slows depletion of CD4 T cells in HIV type 1-infected patients. In addition, our studies over the last 10 years have indicated a strong association between KRG intake and gross deletion in the $g \Delta n e f[18,19,21]$. However, these previous reports have suffered from important limitations, including lack of baseline and earlier samples within 3 years after initiating KRG intake. Thus, although we were able to establish that the occurrence of $\mathrm{g} \Delta$ nef depends on the amount of KRG intake [19], we could not determine the relationship between the duration of KRG intake and the detection of $\mathrm{g} \Delta$ nef.

In the present study, we focused on the first 3 years of KRG intake. Considering a sampling interval of about 6 months, the median time for the detection of $g \Delta n e f$ might be less than the 13 months estimated here. In any case, g $\Delta$ nef occurs considerably earlier than the median time 67-month of our previous study [18].

Among the three patients who revealed g $\Delta$ nef at baseline, patient 01-99 was infected with HIV-1 through her husband, who was diagnosed with HIV-1 infection in 1987 and had taken KRG since 1994, suggesting that the wife's g $\Delta$ nef might have resulted from previous virus exposure to KRG. The husband, who has remained healthy in the absence of HAART for 22 years, did not reveal $\mathrm{g} \Delta n e f$ at baseline [20], but did have a high proportion of gross deletion in 5'-LTR/gag [20]. Our data show that a high frequency of $\mathrm{g} \Delta$ nef is directly associated with KRG intake rather than host factors or introduction of a genetically defective HIV-1 strain in Korea.

Regarding prognosis, except one patient 04-397 with the worst HLA allele, all patients show relative good prognosis. In detail, 91-22 who had been infected with HIV via transfusion in December 1989 remains healthy for 20 years in the absence of HAART. After this study 


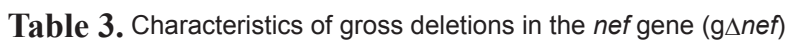

\begin{tabular}{|c|c|c|c|c|c|c|c|}
\hline Patient code & $\begin{array}{l}\text { Day of } \\
\text { samplin }\end{array}$ & $\begin{array}{l}\text { No. of bands } \\
\text { by } \text { PCR }^{1)}\end{array}$ & $\begin{array}{l}\text { No. of PCR } \\
\text { reactions } \\
\text { with } g \Delta n e f^{2)}\end{array}$ & Size of $\Delta(b p)^{3)}$ & $\begin{array}{l}\text { Beginning nt. } \\
\text { relative to } \\
\text { HIV-1 NL4-3 }\end{array}$ & $\begin{array}{l}\text { D outside } \\
\mathrm{g} \Delta \text { nef (bp) }\end{array}$ & $\begin{array}{c}\text { GenBank } \\
\text { accession No. }\end{array}$ \\
\hline \multirow[t]{7}{*}{$89-14$} & Jul 91 & 2 & 1 & 451 & 8,859 & & \\
\hline & Dec 92 & 2 & 1 & 545 & 8,826 & & HM747120 \\
\hline & Jun 93 & 2 & 1 & 408 & 9,021 & & HM369815 \\
\hline & & 2 & 1 & 321 & 8,922 & & HM369818 \\
\hline & Dec 93 & 2 & 1 & 453 & 8,868 & & HM369824 \\
\hline & May 94 & 2 & 4 & 544 & 8,698 & $89 \mathrm{env}$ & \\
\hline & Dec 94 & 2 & 4 & 544 & 8,698 & $89 \mathrm{env}$ & \\
\hline \multirow[t]{2}{*}{$91-22$} & Dec 02 & 1 & 1 & 744 & 8,798 & & AY221678 \\
\hline & & 1 & 1 & 511 & 8,882 & & AY221679 \\
\hline \multirow[t]{10}{*}{$92-48$} & Oct 92 & 2 & 1 & 438 & 8,765 & $20 \mathrm{env}$ & \\
\hline & Sep 93 & 2 & 2 & 504 & 8748 & $29 \mathrm{env}$ & HM747122 \\
\hline & & 2 & 1 & 297 & 8994 & & HM369874 \\
\hline & Dec 93 & 2 & 1 & 549 & 8698 & $89 \mathrm{env}$ & HM747123 \\
\hline & Jun 94 & 2 & 4 & 256 & 9060 & & HM369882 \\
\hline & & 2 & 2 & 352 & 8822 & & HM369883 \\
\hline & Dec 94 & 2 & 2 & 549 & 8698 & $89 \mathrm{env}$ & HM747126 \\
\hline & $\mathrm{M}=5$ & 2 & 2 & 549 & 8698 & $89 \mathrm{env}$ & HM747127 \\
\hline & Mray 95 & 2 & 2 & 437 & 8819 & & HM369886 \\
\hline & Oct 95 & 2 & 1 & 452 & 8862 & & HM369888 \\
\hline \multirow[t]{2}{*}{$95-87$} & May 07 & 2 & 1 & 373 & 8,871 & & HM369905 \\
\hline & Feb 08 & 2 & 1 & 324 & 8,913 & & HM369911 \\
\hline \multirow[t]{4}{*}{$96-51$} & Apr 02 & 1 & 1 & 104 & 8,707 & $79 \mathrm{env}^{4)}$ & DQ121943 \\
\hline & Dec 02 & 1 & 1 & ND & ND & & \\
\hline & Oct 03 & 2 & 1 & 630 & 8,749 & $38 \mathrm{env}$ & DQ121946 \\
\hline & & 2 & 1 & 642 & 8,716 & 71env & DQ121948 \\
\hline $97-116$ & Dec 02 & 2 & 1 & 331 & 8,764 & $13 \mathrm{env}$ & HM369950 \\
\hline \multirow[t]{5}{*}{ 01-99 } & Apr 01 & 2 & 1 & 242 & 8,916 & & HM369964 \\
\hline & Sep 02 & 1 & 1 & 211 & 8,895 & & AY21650 \\
\hline & & 1 & 1 & 312 & 9,030 & & AY221651 \\
\hline & Mar 03 & 2 & 1 & 252 & 9,055 & & HM369970 \\
\hline & Sep 03 & 2 & 1 & 636 & 8,751 & $25 \mathrm{env}$ & HM747130 \\
\hline \multirow[t]{3}{*}{ 01-179 } & Mar 05 & 1 & 1 & 497 & 8,873 & & DQ122080 \\
\hline & Mar 06 & 2 & 1 & 311 & 8,910 & & \\
\hline & Sep 06 & 2 & 1 & 281 & 8,795 & & \\
\hline \multirow[t]{2}{*}{$03-493$} & Jun 07 & 2 & 1 & 379 & 9,040 & & HM370007 \\
\hline & Jun 08 & 2 & 3 & 544 & 8,698 & $89 \mathrm{env}$ & HM747133 \\
\hline \multirow[t]{2}{*}{$04-397$} & Jan 06 & 2 & 1 & 624 & 8,783 & 3 env & HM747135 \\
\hline & Sep 07 & 2 & 1 & 24 & 8,757 & $19 \mathrm{env}$ & HM747136 \\
\hline
\end{tabular}

1) 1 and 2 denote single short band only and wild type with g $\Delta$ nef, respectively.

${ }^{2)}$ Number of PCR products (of four PCR amplicons per sample) with g $\Delta$ nef.

${ }^{3)} \Delta(\mathrm{bp})$ denotes deletion (base pair).

${ }^{4)} 89 \mathrm{env}$ denotes 89 -bp deletion in the env gene.

period, the patient revealed another $\mathrm{g} \Delta$ nef $(1 / 20)$ in June 2008 and gross deletion/premature stop codons in the vif gene (1/39) as well as in the $5^{\prime} \mathrm{LTR} / \mathrm{gag}(7 / 26)$. Patient 97-116 are also healthy without decrease in 


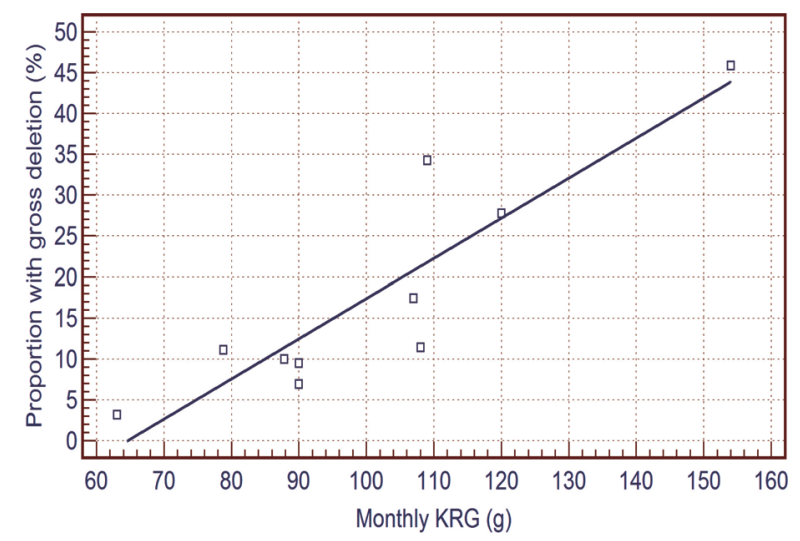

Fig. 2. Correlation between the monthly amount of Korean red ginseng (KRG) intake and the proportion of gross deletion in the nef gene during KRG-intake $(r=0.89, p<0.001)$.

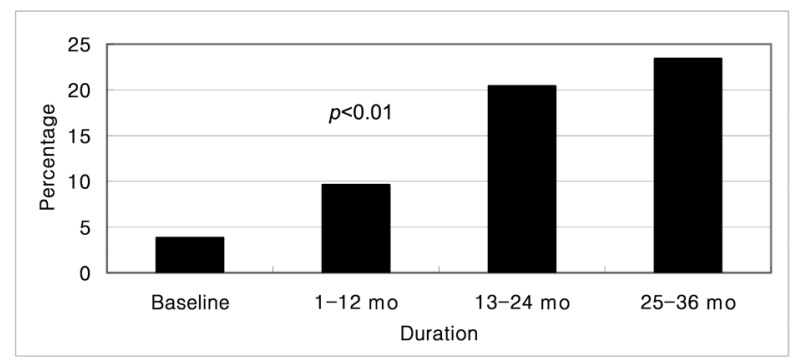

Fig. 3. Relationship between the duration of Korean red ginseng intake and the proportion of nef gene ( $\mathrm{g} \Delta n e f)$. The proportion of $\mathrm{g} \Delta$ nef was $3.8 \%$ at baseline, $9.6 \%$ at 1 to 12 months, $20.4 \%$ at 13 to 24 months, and $23.4 \%$ at 25 to 36 months $(p<0.01)$.

CD4 T cell for 13 years. Patients 96-51 and 03-493 had maintained CD4 T cell count more than $500 / \mu \mathrm{L}$ for 13 and 6 years, respectively. Patient 01-99 has maintained CD4 T cell count for 9 years. However, despite KRG and zidovudine therapy, patient 89-14 died of acquired immunodeficiency syndrome in May 1996 before introduction of HAART in Korea. Patient 9248 committed suicide in 1998 on HAART. Patients 9651 and 04-397 began to take HAART from September 2009 and September 2007, respectively.

Despite the association between KRG intake and $\mathrm{g} \Delta$ nef we do not know the mechanism for the nef deletions. In the same patients, the proportion with gross deletion in 5 ' $\mathrm{LTR} / \mathrm{gag}$ was $23.1 \%$ during KRG intake (data not shown). In addition, G-to-A hypermutations in the vif and pol genes are significantly high during KRG intake (data not shown). In other words, the g $\Delta$ nef is not the only gene affected by KRG intake. It seems that whole HIV-1 genes are nonspecifically affected by KRG intake $[13,20,21]$. Therefore, we can speculate that both direct antiviral and indirect immunological mechanisms are involved together with decrease in chronic immune activation in CTL function [12,16,17]. With respect to the antiretroviral effects of ginseng, several reports also support our data. It is known that several ginsenosides including polyacetyleneginsenoside-Ro from Panax ginseng and xylanase from Panax notoginseng inhibited the replication of HIV-1 [27-29]. In addition, it is known that ginsenosides $\mathrm{Rb} 1, \mathrm{Rb} 2, \mathrm{Rb} 3$, and $\mathrm{Rc}$ have anti-HIV replication in vitro (patent, CN1745756A).

Regarding immunological mechanism, it seems that $\mathrm{g} \Delta$ nef might indirectly result from the enhancement of innate immunity than adaptive immunity [30-32], immune modulation toward Th1-cytokines [33,34], antiinflammatory response through TLR4 induced NF$k \mathrm{~B}[35]$ as well as the attenuation of hyper-immune activation state $[12,16]$. In particular, it appears that the LTR region including g $\Delta$ nef is more fragile to KRG intake than are other regions of HIV-1 because HIV-1 gene expression is modulated by cis-acting regulatory elements in the LTRs [36]. In addition, approximately 200 substances, such as ginsenoside, polysaccharides, polyacetylenes, peptides, and amino acids, have been isolated from Korean ginseng [37]. Therefore, it might not be easy to elucidate the mechanism. Through this study, we confirmed that $\mathrm{g} \Delta n e f$ is inducible by KRG intake although future study is required whether the $\mathrm{g} \Delta$ nef is caused by ginsenosides or polysaccharide.

\section{ACKNOWLEDGEMENTS}

This work was supported by a grant from the Korean Society of Ginseng funded by the Korea Ginseng Corporation (2007-2009).

\section{REFERENCES}

1. Huang Y, Zhang L, Ho DD. Characterization of gag and pol sequences from long-term survivors of human immunodeficiency virus type 1 infection. Virology 1998;240:3649.

2. Zhang L, Huang Y, Yuan H, Tuttleton S, Ho DD. Genetic characterization of vif, vpr, and vpu sequences from longterm survivors of human immunodeficiency virus type 1 infection. Virology 1997;228:340-349.

3. Miura T, Brockman MA, Brumme CJ, Brumme ZL, Carlson JM, Pereyra F, Trocha A, Addo MM, Block BL, Rothchild AC, et al. Genetic characterization of human immunodeficiency virus type 1 in elite controllers: lack of gross genetic defects or common amino acid changes. J Virol 2008;82:8422-8430.

4. Deacon NJ, Tsykin A, Solomon A, Smith K, Ludford- 
Menting M, Hooker DJ, McPhee DA, Greenway AL, Ellett A, Chatfield C, et al. Genomic structure of an attenuated quasi species of HIV-1 from a blood transfusion donor and recipients. Science 1995;270:988-991.

5. Churchill MJ, Rhodes DI, Learmont JC, Sullivan JS, Wesselingh SL, Cooke IR, Deacon NJ, Gorry PR. Longitudinal analysis of human immunodeficiency virus type $1 \mathrm{nef} /$ long terminal repeat sequences in a cohort of longterm survivors infected from a single source. J Virol 2006;80:1047-1052.

6. Deeks SG, Walker BD. Human immunodeficiency virus controllers: mechanisms of durable virus control in the absence of antiretroviral therapy. Immunity 2007;27:406416.

7. Palella FJ Jr, Delaney KM, Moorman AC, Loveless MO, Fuhrer J, Satten GA, Aschman DJ, Holmberg SD. Declining morbidity and mortality among patients with advanced human immunodeficiency virus infection. HIV Outpatient Study Investigators. N Engl J Med 1998;338:853-860.

8. Li CP, Li RC. An introductory note to ginseng. Am J Chin Med (Gard City N Y) 1973;1:249-261.

9. Sakure S, Negi VD, Mitra SK, Nandakumar KS, Chakravortty D. Vaccine with herbal adjuvant-a better cocktail to combat the infection. Vaccine 2008;26:3387-3388.

10. Rivera E, Ekholm PF, Inganas M, Paulie S, Gronvik KO. The $\mathrm{Rb} 1$ fraction of ginseng elicits a balanced Th1 and Th2 immune response. Vaccine 2005;23:5411-5419.

11. Cho YK, Kim YB, Choi BS, Cho YJ, Suh IS, Shin YH. The increase of $\mathrm{T}$ cell by Korean red ginseng in HIV-infected individuals. J Korean Soc Microbiol 1994;29:371379.

12. Cho YK, Kim YK, Lee I, Choi MH, Shin YO. The effect of Korean red ginseng (KRG), zidovudine (ZDV), and the combination of KRG and ZDV on HIV-infected patients. J Korean Soc Microbiol 1996;31:353-360.

13. Cho YK, Kim YB, Kim YK, Lee HJ, Oh WI. Sequence analysis of $\mathrm{C} 2-\mathrm{V} 3$ region of human immunodeficiency virus type 1 gp120 and its correlation with clinical significance: the effect of long-term intake of Korean red ginseng on env gene variation. J Korean Soc Microbiol 1997;32:611-623.

14. Cho YK, Sung H, Lee HJ, Joo CH, Cho GJ. Long-term intake of Korean red ginseng in HIV-1-infected patients: development of resistance mutation to zidovudine is delayed. Int Immunopharmacol 2001;1:1295-1305.

15. Cho YK, Sung H, Kim TK, Lim JY, Jung YS, Kang SM. Korean red ginseng significantly slows CD4 T cell depletion over 10 years in HIV-1 infected patients: association with HLA. J Ginseng Res 2004;28:173-182.

16. Sung H, Kang SM, Lee MS, Kim TG, Cho YK. Korean red ginseng slows depletion of CD4 T cells in human immunodeficiency virus type 1-infected patients. Clin Diagn Lab Immunol 2005;12:497-501.

17. Cho YK, Sung HS. Effect of Korean red ginseng on serum soluble CD8 in HIV-1- infected patients. J Ginseng Res 2007; 31:175-180.

18. Cho YK, Lim JY, Jung YS, Oh SK, Lee HJ, Sung H. High frequency of grossly deleted nef genes in HIV-1 infected long-term slow progressors treated with Korean red ginseng. Curr HIV Res 2006;4:447-457.

19. Cho YK, Jung YS, Sung H. Frequent gross deletion in the HIV type 1 nef gene in hemophiliacs treated with Korean Red Ginseng: inhibition of detection by highly active antiretroviral therapy. AIDS Res Hum Retroviruses 2009;25:419-424.

20. Cho YK, Jung YS. High frequency of gross deletions in the 5' LTR and gag regions in HIV type 1-infected longterm survivors treated with Korean red ginseng. AIDS Res Hum Retroviruses 2008;24:181-193.

21. Cho YK, Jung YS, Sung H, Sim MK, Kim YK. High frequency of gross deletions in 5' LTR/gag and nef genes in patients infected with CRF02_AG of HIV type 1 who survived for over 20 years: an association with Korean red ginseng. AIDS Res Hum Retroviruses 2009;25:535541.

22. Sung H, Jung YS, Cho YK. Beneficial effects of a combination of Korean red ginseng and highly active antiretroviral therapy in human immunodeficiency virus type 1-infected patients. Clin Vaccine Immunol 2009;16:11271131.

23. Cho YK, Foley BT, Sung H, Kim YB, Kim JH. Molecular epidemiologic study of a human immunodeficiency virus 1 outbreak in haemophiliacs B infected through clotting factor 9 after 1990. Vox Sang 2007;92:113-120.

24. Cho YK, Lee HJ. The detection of ICD p24 antigen predicts bad prognosis in HIV-1 infected patients. J Korean Soc Virol 1996;26:259-267.

25. Scorza SR, Fabio G, Lazzarin A, Eisera NB, Moroni M, Zanussi C. HLA-associated susceptibility to acquired immunodeficiency syndrome in Italian patients with humanimmunodeficiency-virus infection. Lancet 1986;2:11871189.

26. Itescu S, Mathur-Wagh U, Skovron ML, Brancato LJ, Marmor M, Zeleniuch-Jacquotte A, Winchester R. HLAB35 is associated with accelerated progression to AIDS. J Acquir Immune Defic Syndr 1992;5:37-45.

27. Wei Y, Ma CM, Hattori M. Anti-HIV protease triterpenoids from the acid hydrolysate of Panax ginseng. Phytochem Lett 2009;2:63-66.

28. Zhang H, Lu Z, Tan GT. Polyacetylenginseng-Ro, a novel 
triterpene saponin from Panax ginseng. Tetrahedron Lett 2002;43:973-977.

29. Lam SK, Ng TB. A xylanase from roots of sanchi ginseng (Panax notoginseng) with inhibitory effects on human immunodeficiency virus-1 reverse transcriptase. Life Sci 2002;70:3049-3058.

30. See DM, Broumand N, Sahl L, Tilles JG. In vitro effects of echinacea and ginseng on natural killer and antibodydependent cell cytotoxicity in healthy subjects and chronic fatigue syndrome or acquired immunodeficiency syndrome patients. Immunopharmacology 1997;35:229-235.

31. Ahn JY, Choi IS, Shim JY, Yun EK, Yun YS, Jeong G, Song JY. The immunomodulator ginsan induces resistance to experimental sepsis by inhibiting Toll-like receptor-mediated inflammatory signals. Eur J Immunol 2006;36:3745 .

32. Nakaya TA, Kita M, Kuriyama H, Iwakura Y, Imanishi J. Panax ginseng induces production of proinflammatory cytokines via toll-like receptor. J Interferon Cytokine Res 2004;24:93-100.
33. Kim KH, Lee YS, Jung IS, Park SY, Chung HY, Lee IR, Yun YS. Acidic polysaccharide from Panax ginseng, ginsan, induces Th1 cell and macrophage cytokines and generates LAK cells in synergy with rIL-2. Planta Med 1998;64:110115 .

34. Larsen MW, Moser C, Hoiby N, Song Z, Kharazmi A. Ginseng modulates the immune response by induction of interleukin-12 production. APMIS 2004;112:369-373.

35. Yang CS, Yuk JM, Ko SR, Cho BG, Sohn HJ, Kim YS, Wee JJ, Do JH, Jo EK. Compound K rich fractions regulate $\mathrm{NF}-\kappa_{\mathrm{B}}$-dependent inflammatory responses and protect mice from endotoxin-induced lethal shock. J Ginseng Res 2008;32;315-323.

36. Jones KA, Kadonaga JT, Luciw PA, Tjian R. Activation of the AIDS retrovirus promoter by the cellular transcription factor, Sp1. Science 1986;232:755-759.

37. Attele AS, Wu JA, Yuan CS. Ginseng pharmacology: multiple constituents and multiple actions. Biochem Pharmacol 1999;58:1685-1693. 